\title{
Obituary
}

\section{Remembering Mehmet Genç (1934-2021), economic historian of the Ottoman Empire}

\author{
Şevket Pamuk
}

I first learned of Mehmet Genç in the 1970s when I was a doctoral student. The papers of an economic history conference held at Hacettepe University were published as a book and one of them caught my attention. In one of his earliest papers, Genç was making an important proposal for Ottoman economic history studies at the time. Supported by a strong economic history framework, he wrote that it may be possible to establish the rates of growth of different sectors of Ottoman manufacturing during the seventeenth and eighteenth centuries by tracing the changes over time in the sale prices of Ottoman tax units called malikane. For a young academic who was thinking about ways of using the Ottoman archives for quantitative economic history, this was a novel and exciting approach. In later years this method did not prove practical because the prices of many of the malikanes did not change over time. Nonetheless, I had learned Genç's name and became acquainted with his work.

From the earliest days I met Genç, I became aware I was talking to an exceptional scholar who had read widely in social sciences, economics, history, and economic history. Genç was always ready to share his ideas and insights. He was always open to the exchange of ideas, had an exceptional sense of humor, and enjoyed telling jokes. All historians who worked in the archives were aware how well he knew the archives and how much he was willing to help the researchers working there.

What made Genç special, in my opinion, was not his knowledge of the Ottoman archives but his ability to bring together his knowledge of the archives with his knowledge of economics and economic history. As Fernand Braudel and many others have often emphasized, it was his knowledge of economics and economic history that enabled Mehmet Genç to ask the important questions in Ottoman economic history and develop his own answers.

Boğaziçi University, Istanbul, Turkey; pamuk@boun.edu.tr 
The big problems Genç focused on and the big questions he asked in Ottoman economic history revolved around what this large empire was able to do well and where it had problems. As he stated in his writings, he explored how the empire was able to expand so rapidly and how it was able to survive for centuries after it began to lose territories, where it found the energy to resist even though European countries to its west were developing and getting stronger with time.

In the questions Genç asked and in the answers he provided, the state has been at the center. Because the documents they work with come mostly if not entirely from the state archives and are prepared by the state, Ottoman historians have been rightfully criticized for being state-centric. It is certainly true that for good economic history, it is not sufficient to look at the state alone but to take into account other structures and actors as well. It is also true, however, that many of the key questions in economic history cannot be satisfactorily answered without taking the state into account. States, especially the states of large empires, play key roles in shaping, adapting, and transforming the institutions of the empires. In recent decades, economics and economic history have been placing, once again, greater emphasis on the role of the state, and more generally, institutions. In short, while staying close to the documents of the state certainly has its drawbacks, looking at the state as Genç did in a large part of his work certainly had its advantages as well.

One of the most important hypotheses that Genç developed in the small number of insightful and influential studies he published in Ottoman economic history concerned the priorities of the Ottoman state in economic and related matters. He pointed to three priorities: fiscalism or tax collection and the balancing of the state budget; provisioning of the urban areas and above all the capital city; and traditionalism or the preservation of what was perceived as the traditional order and social structure. To be clear, these principles do not tell us how the economy of the empire worked because the state did not have the power to direct the economy to that extent. However, we can agree that these reflected the priorities and goals of the Ottoman state in economic matters. To what extent the Ottoman state was able to stay close to these goals and to what extent the outcomes were consistent with these priorities varied, however, from one period to another.

Surely, these priorities were not unique to the Ottomans. Before the Industrial Revolution and the age of industrial capitalism, all states, to varying degrees, had to take these priorities into account. In fact, more than its power, the priorities Genç identified for the Ottoman state reflected the limits to the powers of the Ottoman state in economic matters, and more generally, they reflected the limits to the powers of other pre-industrial or pre-modern states, especially of states of large land-based empires. 
Mehmet Genç made important contributions to our understanding of the ${ }_{\frac{\mathrm{m}}{z}}^{\mathrm{z}}$ economic history of one of longest-lasting empires in history. As he often emphasized, his legacy and his contributions, including his focus on the priorities of the Ottoman state, would be best served if they continue to be discussed and debated rather than merely accepted by historians and economic historians. For example, exploring the reasons and structures behind these priorities will help us better understand the Ottoman economy as well its society and politics. Only then will it be possible to better understand the economic history of this large empire and its place in world history. 